\title{
Nod Factor Induction of Reactive Oxygen Species Production Is Correlated with Expression of the Early Nodulin Gene rip1 in Medicago truncatula
}

\author{
Senthil K. Ramu, ${ }^{1}$ Hui-Mei Peng, ${ }^{1}$ and Douglas R. Cook ${ }^{2}$ \\ 'Department of Plant Pathology and Microbiology, Texas A\&M University, College Station, 77843-2132 U.S.A.; \\ ${ }^{2}$ Department of Plant Pathology, One Shields Avenue, University of California, Davis, 95616 U.S.A.
}

Submitted 6 December 2001. Accepted 5 March 2002.

Plant genes that are specifically activated by the rhizobial lipochitooligosaccharide signal molecule (Nod factor) in legume hosts are collectively referred to as nodulins. Although nodulin gene expression is both spatially and temporally correlated with symbiosis, the function of these genes and the molecular events underlying their expression remain unknown. Sequence analysis of rip1, an early nodulin gene encoding a putative peroxidase protein, revealed the existence of sequence motifs with homology to reactive oxygen species (ROS) responsive cis elements. Here we report that recognition of compatible Nod factor rapidly stimulates a spatially localized production of reactive oxygen species in legume roots. Sinorhizobium meliloti mutants that produce an altered Nod factor structure and a nonnodulating plant mutant, dmil-1, that is implicated in Nod factor signal transduction are equally impaired in the ability to elicit ROS production and rip1 expression. Interestingly, both rip1 transcription and ROS production exhibit the same tissue-specific pattern of localization. Moreover, exogenous hydrogen peroxide is sufficient to activate rip1 transcription. Taken together, these results suggest that ROS production is a consequence of specific Nod factor perception and implicate $\mathrm{H}_{2} \mathrm{O}_{2}$ produced during this response as a mediator of Nod factor-induced rip1 expression.

The symbiotic interaction between rhizobia and leguminous plants results in the development of a root nodule, a specialized plant organ in which nodule-inducing bacteria and their legume host conduct symbiotic nitrogen fixation (Long 1996). Rhizobial nod genes specify the synthesis of a lipochitooligosaccharide signal molecule called Nod factor (Dénarié et al. 1996). Nod factors play a pivotal role in the initial stages of symbiosis and are capable of eliciting symbiotic gene expression and nodule morphogenesis on legume hosts with the same specificity as the rhizobial symbiont (Dénarié et al. 1996). Purified Nod factors induce plant responses that are reminiscent of signaling events in other eukaryotic systems. For example, in root hairs of Medicago species, Nod factors produced by compatible Sinorhizobium meliloti induce plasma membrane depolari-

Corresponding author: Douglas R. Cook; E-mail drcook@ucdavis.edu; Telephone: +530.754.6561; Fax: +530.754 .6617$

Current address for S. K. Ramu: Department of Genetics, Harvard Medical School. zation (Erhardt et al. 1992), intracellular alkalization (Felle et al. 1996), and calcium spiking (Erhardt et al. 1996). These inducible responses occur within minutes to hours of Nod factor application and may be part of a series of cellular events that lead to symbiotic development (Downie and Walker 1999).

In addition to several electrophysiological and cellular changes, Nod factors specifically trigger the expression of plant genes referred to as nodulin genes in legume roots. Of the known nodulin genes, one of the most rapidly induced is ripl, encoding a peroxidase protein. Nod factor is both necessary and sufficient for ripl induction, and Nod factor-producing $S$. meliloti induces tissue specific expression of ripl that is tightly correlated with early symbiotic processes, first in the differentiating root epidermis and then in nascent nodule primordia (Cook et al. 1995; Peng et al. 1996).

Despite the importance of Nod factor as an elicitor of early symbiotic responses, including plant gene expression, the molecular mechanisms underlying Nod factor perception and signal transduction remain unclear. Genetic analyses of model legume systems, such as Medicago truncatula (Cook 1999) and Lotus japonicus (Handberg and Stougaard 1992), have recently led to the identification of several host genes that are required for proper symbiotic development (Penmetsa and Cook 1997; Catoira et al. 2001). In particular, a genetic pathway for Nod factor signal transduction has been proposed based on the identification of multiple alleles at four loci that are pleiotropic for a suite of Nod factor-induced responses in M. truncatula (Catoira et al. 2000; Wais et al. 2000).

In conjunction with these genetic analyses, we are investigating the mechanism of transcriptional activation of ripl by compatible Sinorhizobium meliloti and Nod factor. Based on sequence analysis of the ripl promoter, we identified three copies of a putative OCS (octopine synthase) element and eight copies of a putative OBF binding protein (OBP) element positioned within $500 \mathrm{bp}$ of the ripl transcription start site (Peng et al. 1996) (Fig. 1). OCS and OBP motifs have been identified as cis regulatory elements of certain plant genes that are transcriptionally activated by $\mathrm{H}_{2} \mathrm{O}_{2}$ and, in several cases, the corresponding gene products function as protectants from oxidative damage or from pathogen ingress (Zhang et al. 1995; Chen et al. 1996). The existence of OCS- and OBP-like motifs in the ripl promoter prompted us to explore the possible involvement of ROS in ripl transcription during symbiosis.

Here, we present evidence that recognition of Nod factor can stimulate the tissue-specific production of superoxide radical, coincident with the temporal and spatial distribution of ripl 
transcript during early nodulation. Using $S$. meliloti mutants producing an inactive structural variant of Nod factor and a plant mutant defective for early Nod factor-induced responses, a functional link was established between the Nod factor signal and elicitation of this ROS response. We have also determined that the exogenous application of $\mathrm{H}_{2} \mathrm{O}_{2}$ is sufficient to induce ripl expression. These results suggest ROS production is a consequence of specific Nod factor perception and implicate $\mathrm{H}_{2} \mathrm{O}_{2}$ produced during this response as a mediator of Nod factor-induced ripl expression.

\section{RESULTS}

Exogenous hydrogen peroxide is sufficient for rip1 induction.

DNA sequence analysis of the ripl promoter region revealed the presence of putative OCS and OBP cis elements in close proximity to the transcription initiation site (Fig. 1). OCS and OBP cis elements are common in the promoters of plant genes that are induced by pathogens or pathogen elicitors. In such cases, these cis elements are implicated in transcriptional induction by reactive oxygen species (ROS) and, in particular, by $\mathrm{H}_{2} \mathrm{O}_{2}$ (Chen et al. 1996).

To ascertain whether the transcription of ripl is responsive to exogenous $\mathrm{H}_{2} \mathrm{O}_{2}$, we treated uninoculated roots with varying concentrations of $\mathrm{H}_{2} \mathrm{O}_{2}$ and assayed ripl transcript levels by Northern blot analysis. In parallel to the analysis of ripl expression, we monitored the induction of a glutathione-S-transferase gene $(g s t)$. GSTs function as an antioxidant (Daniel

A

$$
\begin{array}{ll}
1 & -459 \\
2 & -428 \\
3 & -369 \\
4 & -296 \\
5 & -265 \\
6 & -187 \\
7 & -127 \\
8 & -96
\end{array}
$$

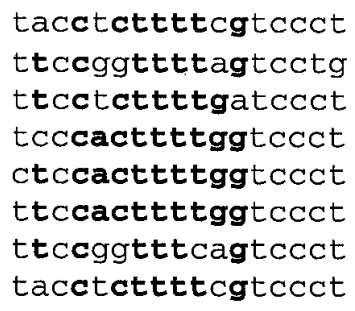

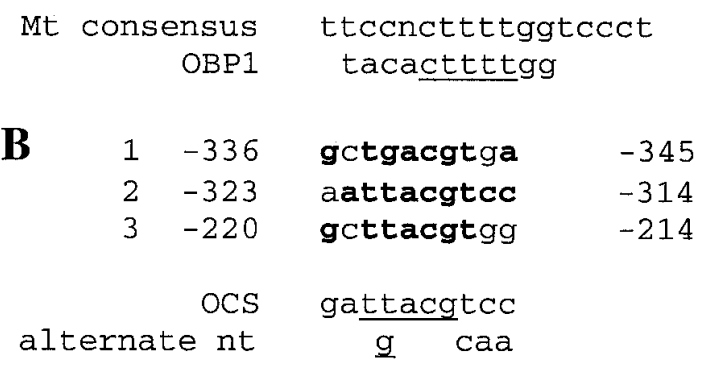

Fig. 1. Structure of OCS- (octopine synthase) and OBF binding proteinlike sequence motifs $5^{\prime}$ of the ripl transcription initiation site. A, Sequence of individual 17-bp repeats within the rip1 promoter region that share sequence similarity with the 11-bp OBP1 binding site (OBS) of the Arabidopsis gst6 promoter (Chen et al. 1996). Numbering corresponds to the position of each repeat relative to the transcription initiation site determined by Peng and associates (1996). Bolded nucleotides share identity with OBP1. Mt consensus $=$ the consensus of the Medicago truncatula repeats. 'ctttt' corresponds to the footprint of OBP1 (Chen et al. 1996). B, Sequence of three 10-bp repeats within the rip1 promoter region that share sequence similarity with the OBF5 binding site (OCS) of the Arabidopsis gst6 promoter (Chen et al. 1996). Numbering corresponds to the position of each repeat relative to the transcription initiation site of ripl. Bolded nucleotides share identity with the OCS consensus. The $\operatorname{tg}(\mathrm{t}) \mathrm{acg}$ motif represents the DNase I footprint of OBF5 (Chen et al. 1996). The OCS consensus sequence is based on comparison of 10 pathogen promoters including CaMV 35S, NOS, and ocs promoters (Bouchez et al. 1989).
1993) and, by analogy to other plant systems, GST gene expression should provide a reporter for $\mathrm{H}_{2} \mathrm{O}_{2}$-responsive transcription. As shown in Figure 2A, increasing levels of $\mathrm{H}_{2} \mathrm{O}_{2}$ were correlated with increased levels of ripl transcript. Moreover, in replicate experiments, both ripl and gst exhibited minimal induction in the range of $200 \mu \mathrm{M} \mathrm{H}_{2} \mathrm{O}_{2}$ and maximum induction at 2 to $5 \mathrm{mM} \mathrm{H} \mathrm{O}_{2}$. These results are in agreement with the dose-dependent induction of $g$ st transcript by $\mathrm{H}_{2} \mathrm{O}_{2}$ reported for Arabidopsis (Chen et al. 1996) and soybean (Levine et al. 1994).

Because both $S$. meliloti Nod factors (Cook et al. 1995) and $\mathrm{H}_{2} \mathrm{O}_{2}$ are sufficient for ripl induction, it is possible that early responses to Nod factor perception might include increases in ROS. As an indirect test of this hypothesis, we analyzed gst expression in roots $12 \mathrm{~h}$ after inoculation with wild-type $S$. meliloti or its Nod factor-deficient derivative SL44. Strain SL44 contains a deletion for nod genes nodD1 to nodABC and is, therefore, null for Nod factor biosynthesis. As shown in Figure $2 \mathrm{~B}$, inoculation with wild-type $S$. meliloti, but not strain SL44, was correlated with increased gst transcript. Thus, in addition to induction of early nodulin genes such as ripl, Nod factor is likely to activate an endogenous antioxidant pathway.

\section{$S$. meliloti Nod factor induces ROS production in the nodulation zone of $M$. truncatula roots.}

The rapid induction of ripl by exogenous $\mathrm{H}_{2} \mathrm{O}_{2}$ and the Nod factor-dependent induction of gst in roots prompted us to explore the possibility that Nod factor can elicit ROS in legume roots. By analogy to plant responses to pathogen elicitors, the production of ROS may involve initial production of superoxide radical $\left(\mathrm{O}_{2}^{-}\right)$and its rapid enzymatic conversion into $\mathrm{H}_{2} \mathrm{O}_{2}$ by superoxide dismutase (SOD) (Levine et al. 1994). We monitored superoxide production in situ by treating roots with nitroblue tetrazolium (NBT), a histochemical reagent that reacts with superoxide to a blue formazan precipitate (Doke 1983), and we assessed the specificity of the assay for $\mathrm{O}_{2}{ }^{-}$based on its sensitivity to exogenous SOD. As shown in Figure 3A, the uninoculated root tip is a site of constitutive NBT reduction. Within $12 \mathrm{~h}$ following inoculation with wild-type $S$. meliloti the region of formazan staining had expanded to include tissue adjacent to the root tip, fully encompassing the zone of root hair differentiation (data not shown); by comparison, inoculation with a Nod factor-deficient derivative of $S$. meliloti (strain SL44) failed to increase the zone of formazan staining (Fig.

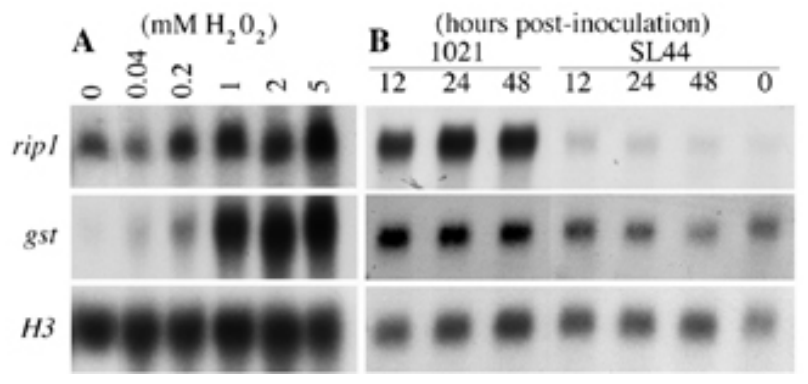

Fig. 2. Gene expression analysis. A, Effect of $\mathrm{H}_{2} \mathrm{O}_{2}$ on ripland gst induction. Northern blots of total root RNA isolated from roots following treament with various concentrations of $\mathrm{H}_{2} \mathrm{O}_{2}$ for $1 \mathrm{~h}$ are shown. Blots were successively probed with ${ }^{32} \mathrm{P}$-labeled ripl, gst, and histone $H 3$ as indicated. B, Analysis of ripl and gst expression in response to Sinorhizobium meliloti 1021 and its Nod factor-deficient derivative SL44. Autoradiographs are of gel blots containing total RNA isolated from roots after inoculation with $S$. meliloti 1021 (Rm 1021) or S. meliloti SL44. Rm1021 and SL44 RNAs were analyzed on the same membrane and represent identical exposure times. Blots were successively probed with ${ }^{32} \mathrm{P}$ labeled ripl, gst, and histone $H 3$ as indicated. Time is reported in hours postinoculation. 
3A). Similar results were obtained with purified Nod factor, which also induced NBT reduction in the root tip proximal zone (Fig. 3B). Both the S. meliloti- and Nod factor-induced responses were effectively blocked by SOD (Fig. 3B), which should rapidly deplete $\mathrm{O}_{2}^{-}$. These results suggest that the molecular species under assay is indeed $\mathrm{O}_{2}^{-}$. Importantly, this Nod factor-induced response is restricted to the root tip proximal zone, where well-characterized Nod factor-specific responses are also localized (Journet et al. 1994; Pingret et al. 1998; Catoira et al. 2000), including the tissue-specific induction of ripl transcript (Cook et al. 1995).

Nodule primordia, which are first macroscopically evident on inoculated roots at $60 \mathrm{~h}$ postinoculation with $S$. meliloti, are also a location of ripl transcript (Peng et al. 1996). NBT reduction to formazan was readily detected in these nascent nodule primordia (Fig. 3C), and formazan formation was blocked by treatment with SOD. However, in contrast to the $12 \mathrm{~h}$ time point (Fig. 3A, 2011 panel) when NBT staining was widely distributed throughout the inoculated symbiotic zone, NBT staining at $60 \mathrm{~h}$ postinoculation was confined to nodule primordia and to vascular tissue (Fig. 3C, top panel). Thus, similar to ripl transcript (Cook et al. 1995; Peng et al. 1996), NBT staining is first evident throughout the symbiotically competent root zone and subsequently focused at sites of nodule initiation.

\section{Superoxide accumulation is spatially coincident} with rip1 transcript.

The spatial distribution of ripl transcript in roots is closely correlated with early symbiotic processes (Cook et al. 1995; Peng et al. 1996). In uninoculated roots, basal levels of ripl transcript are associated with the root tip. By $3 \mathrm{~h}$ following inoculation with the bacterial symbiont, ripl transcript is observed within the differentiating root epidermis, the zone of impending infection by $S$. meliloti, and by $72 \mathrm{~h}$ postinoculation, ripl transcript is evident in nascent nodule primordia, the site of sustained bacterial infection.

To determine the precise spatial correlation between ripl transcript and superoxide production, we performed in situ hybridization and NBT staining on roots immediately before and 12 or $72 \mathrm{~h}$ after inoculation with $S$. meliloti and examined the tissue sections to compare the tissue specificity of both responses. As shown in Figure 4, ripl transcript and superoxide production were spatially coincident throughout all time points analyzed. In uninoculated roots, ripl transcript and superoxide production were localized to cells in the extreme root tip (Fig.
4A and B). At $12 \mathrm{~h}$ postinoculation with $S$. meliloti, prior to bacterial infection, ripl transcript and superoxide production were detected in the differentiating root epidermis and subtending vascular tissue (Fig. 4C and D). At $72 \mathrm{~h}$ postinoculation ripl transcript and superoxide were detected in nascent nodule primordia (Fig. 4E and F). Thus, there is a tight spatial correlation between the presence of ripl transcript and the detection of superoxide accumulation by means of NBT.

\section{Specific aspects of Nod factor structure are required for elicitation of ROS production and rip1 induction.}

Nodulation of Medicago species by S. meliloti has been shown to have a requirement for specific aspects of Nod factor structure. In particular, the presence of a sulfate moiety at the reducing end is necessary for the induction of several host nodulin genes, root hair deformation, rhizobial infection, and the induction of nodule primordia on Medicago (Long 1996; Dénarié et al. 1996). To determine if the production of ROS and ripl induction share specificity for Nod factor structure, we assayed ripl transcript and superoxide production in plants inoculated with wild-type bacterium or with $S$. meliloti nodH mutants that produce Nod factors lacking the reducing-end sulfate (Roche et al. 1991). As shown in Figure 5, a Rm 2011 nodH mutant was unable to induce either ripl expression or superoxide production. Other well-characterized nodH-dependent host responses, including induction of the early nodulin gene ENOD12 and the formation of nodule primordia, were absent from similarly treated plants (data not shown). To confirm these observations, we analyzed ripl transcript and superoxide production following inoculation with a nodH mutant of a second strain of S. meliloti, Rm 1021, and we obtained similar results (data not shown). Thus, Nod factor induction of ripl transcript and superoxide elicitation have a similar stringent requirement for Nod factor O-sulfation, consistent with these responses being products of the same specific Nod factor perception pathway.

\section{A symbiotic mutant of $M$. truncatula is defective for rip1 induction and ROS production.}

Recent genetic analyses in $M$. truncatula have identified numerous single gene mutations that affect the symbiosis with $S$. meliloti. Among these mutants are four loci that are pleiotropic for the absence of several early Nod factor-induced responses and, on this basis, they are proposed to be defective in Nod factor signal transduction (Catoira et al. 2000; Wais et al.
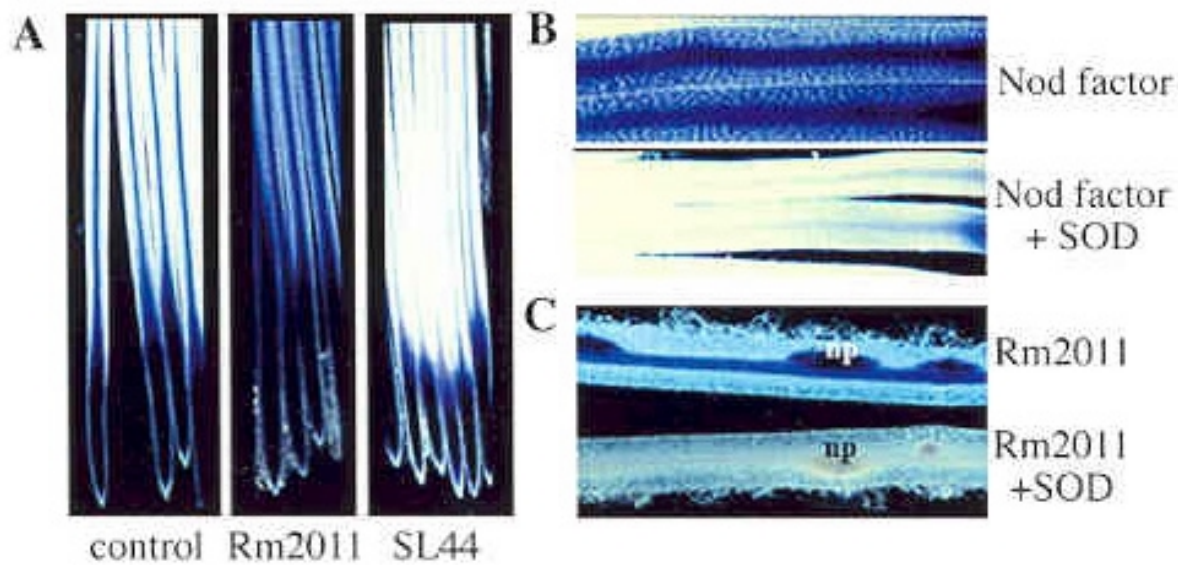

Fig. 3. Localization of superoxide accumulation in whole roots. A, Nitroblue tetrazolium (NBT) staining in the root tip proximal zone. Staining was performed $12 \mathrm{~h}$ postinoculation with Sinorhizobium meliloti (Rm) 2011, the nodD1ABC deletion mutant SL44, or mock-inoculated control. The blue formazan precipitate is indicative of superoxide radical accumulation. B, Nod factor induction of NBT staining and its inhibition by superoxide dismutase (SOD) in the root tip proximal zone. NBT staining was performed $12 \mathrm{~h}$ postinoculation. C, NBT staining in nodule primordia. Staining was performed 60 h postinoculation with $S$. meliloti 2011 with or without superoxide dismutase. $\mathrm{np}=$ nodule primordia. 
2000). One such mutant, named dmil-1 for "doesn't make infections," was tested for induction of superoxide production and ripl expression in response to compatible $S$. meliloti. As shown in Figure 6B, inoculation with $S$. meliloti was unable to elicit either superoxide production or ripl expression in the dmil-1 mutant. In agreement with previous findings (Catoira et al. 2000), we found that dmil-1 is also impaired for enod12 and enod40 expression (Fig. 6B). The lack of S. meliloti-induced superoxide production in dmil-1 plants implies that the mutant is blocked at a stage upstream of ROS generation. To determine if ripl expression in dmil-1 is also insensitive to exogenous $\mathrm{H}_{2} \mathrm{O}_{2}$, we analyzed ripl transcript levels in noninoculated dmil-1 plants following treatment with 1 to $5 \mathrm{mM} \mathrm{H}_{2} \mathrm{O}_{2}$. Interestingly, exogenous $\mathrm{H}_{2} \mathrm{O}_{2}$ was still able to induce ripl expression in dmil-1 roots (Fig. $6 \mathrm{C}$ ).

\section{DISCUSSION}

We have shown that ripl transcription can be activated by exogenous $\mathrm{H}_{2} \mathrm{O}_{2}$ in the absence of Nod factor signal, with a dose response similar to that of other characterized ROS-responsive genes (Chen et al. 1996). Evidence for increases in ROS during symbiotic development comes from the observation that expression of an antioxidant gene, gst, is also increased during symbiosis in a Nod factor dependent manner. Interestingly, among the bacterial genes that are expressed during S. meliloti infection of Medicago species are those with potential roles in protection against reactive oxygen species (Oke and Long 1999), consistent with the possibility that the bacterial symbiont encounters oxidative stress in the plant environment. In support of this hypothesis, SOD-deficient S. meliloti

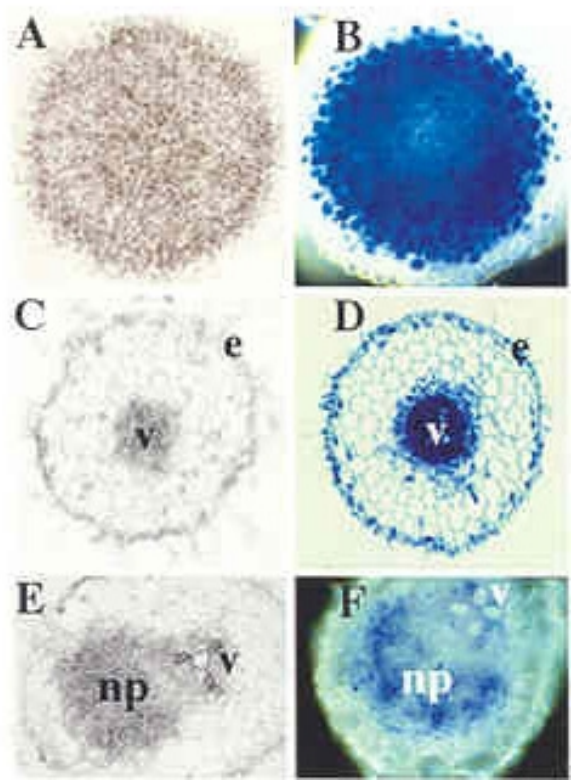

Fig. 4. Spatial distribution of superoxide accumulation in tissues expressing ripl transcript. A, In situ hybridization of an uninoculated root tip (distal $2 \mathrm{~mm}$ ) hybridized with ripl antisense probe. Note the intense signal uniformly distributed in all cell types. For all time points, negative control hybridizations using a sense-strand ripl probe did not produce signal above background (data not shown). B, Transverse section comparable to $\mathrm{A}$, stained with nitroblue tetrazolium (NBT). The blue staining is taken to be indicative of superoxide radical accumulation. C, In situ hybridization of roots $12 \mathrm{~h}$ after inoculation with Sinorhizobium meliloti ABS7. Tissue sections were taken from the $1 \mathrm{~cm}$ root zone immediately adjacent to the root tip. ripl Signal is detected in the epidermis (e) and vascular tissue (v). D, Transverse section comparable to $\mathrm{C}$, stained with NBT. E, In situ hybridization of 72-h nodule primordia (np). F, Transverse section comparable to E, stained with NBT. mutants are only slightly impaired in free-living growth but severely impaired in the ability to colonize host Medicago plants (Santos et al. 2000). We also provide direct evidence that application of Nod factor or inoculation with wild-type S. meliloti leads to an increase in ROS in the symbiotically competent root zone. This response is characterized by increases in $\mathrm{O}_{2}^{-}$in the differentiating root epidermis and root vasculature, as well as in nodule primordia, coincident with the tissue specificity of ripl expression. These spatial and temporal patterns of $\mathrm{O}_{2}^{-}$accumulation are tightly correlated with the known morphological and gene-expression changes that characterize early symbiotic development (Long 1996; Mylona et al. 1995).

The observation that $d m i 1-1$, a plant mutant that is blocked early in symbiotic development, is simultaneously affected for induction of ROS production and ripl expression further strengthens the correlation between these responses and symbiotic signaling. The fact that $d m i l-1$ plants retained the ability to respond to exogenous $\mathrm{H}_{2} \mathrm{O}_{2}$ by expressing ripl and gst suggests that the dmil-1 gene functions at or upstream of ROS generation. Interestingly, the dmil-1 mutant consistently displays elevated basal levels of gst transcript (Fig. 6C) as compared with near-isogenic wild-type plants, suggestive of an altered redox state or response in dmil-1. Additional genetic evidence from inoculation experiments with bacterial mutants suggests that ripl induction and ROS production may be products of the same specific Nod factor perception pathway. In particular, S. meliloti nodH mutants, which produce inactive Nod factors that lack a reducing-end sulfate substitution (Dénarié et al. 1996), were unable to induce either the ROS response or ripl expression in $M$. truncatula roots.

One can envision several possible roles for ROS during symbiosis. One possibility, for example, is that activation of ROS production is a lateral consequence of Nod factor perception, and ripl, being a peroxidase enzyme, could itself function in the metabolism of otherwise harmful $\mathrm{H}_{2} \mathrm{O}_{2}$. Alternatively, ROS could fulfill a critical role in nodulation, for example, by providing oxidant for peroxidase-mediated cell wall modifications during $S$. meliloti infection and nodule organogenesis. Many of the known early nodulin genes, including enod12 (Scheres et al. 1990), enod10 (Lobler and Hirsch 1993),

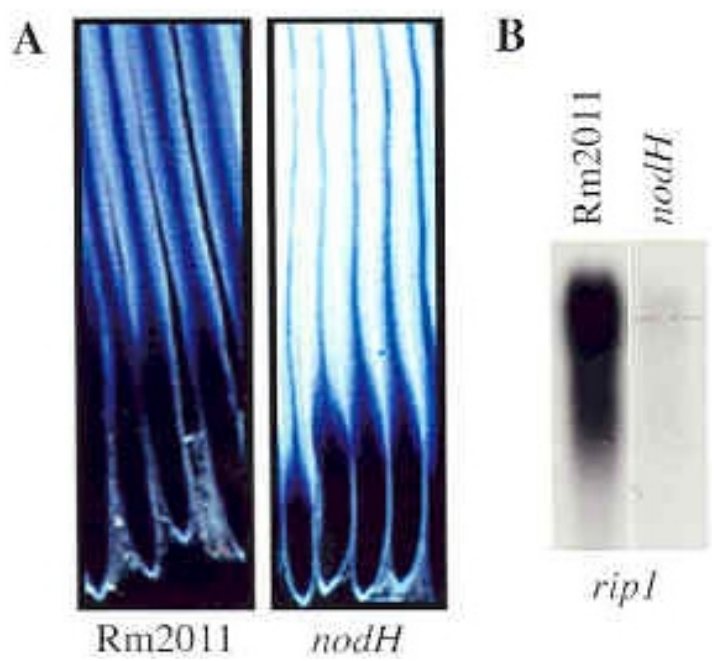

Fig. 5. Effect of wild-type and nodH Sinorhizobium meliloti strains on induction of reactive oxygen species production and ripl expression. A, Nitroblue tetrazolium (NBT) staining of roots inoculated with $S$. meliloti 2011 (Rm2011) or the corresponding Nod factor mutant nodH. All images were taken $12 \mathrm{~h}$ postinoculation. B, Northern blots of RNA isolated from samples inoculated as in A,. Northern blot and NBT staining analyses were conducted in parallel. The blot was probed with ${ }^{32} \mathrm{P}$ labeled rip1. 
enod11 (Cook et al. 1995; Journet et al. 2001) and MtPRP4 (Wilson et al. 1994), encode proline-rich proteins (PRPs) that are members of the extensin superfamily of cell wall proteins (Kieliszewski and Lamport 1994). With the notable exception of enod12, each of these nodule-specific PRPs include a series of tyrosine-containing pentameric motifs that have been implicated in cross-linking of cell wall proteins by a process that involves cell wall-bound peroxidases and $\mathrm{H}_{2} \mathrm{O}_{2}$ (Bradley et al. 1992). The oxidative cross-linking of cell wall proteins, potentially involving ripl peroxidase, could be important at sites of infection thread formation (Salzwedel and Dazzo 1993) or in dividing cells during nodule development. Consistent with this model, Santos and associates (2001) analyzed ROS production during later stages of nodule development (6 to 18 days postinoculation) and observed elevated levels of $\mathrm{O}_{2}^{-}$and $\mathrm{H}_{2} \mathrm{O}_{2}$ at sites of $S$. meliloti infection. Finally, ROS might have a direct role in regulation of plant signaling proteins. Thus, Nod factor-induced changes in redox balance within symbiotically competent root cells could cause alterations in the activity of key signaling proteins, which in turn might activate pathways for $S$. meliloti infection and nodule development. Subtle changes in redox potential can have dramatic affects on protein folding and function (Gamaley and Klyubin 1999), including the activity of transcription factors and small GTP binding proteins, and redox potential may influence the phosphorylation poise that regulates diverse aspects of eukaryotic function. In the analyses presented here, wild-type $S$. meliloti or purified Nod factors consistently induced higher levels of ripl transcript than $\mathrm{H}_{2} \mathrm{O}_{2}$ relative to control untreated tissues. Although this result might imply that $\mathrm{H}_{2} \mathrm{O}_{2}$ acts indirectly to affect ripl transcript levels, interpretation of this result is complicated by the dissimilar nature of the various reactants, i.e., unstable $\mathrm{H}_{2} \mathrm{O}_{2}$, ampipathic Nod factor, and living Sinorhizobium meliloti.

The rhizobium-legume symbiosis shares features in common with plant-pathogen interactions. These features include host genotype-specificity, induction of host genes by microbial elicitors, and redirection of host metabolism (Vance 1983; McKhann and Hirsch 1994). Hirsch and colleagues, in particular, have advanced the hypothesis that, in addition to symbiotic responses, rhizobial Nod factors trigger host defense responses in a manner analogous to pathogen elicitors (McKhann and Hirsch 1994). Interestingly, several studies have shown that pathogen elicitors (specific pathogen avirulence products and fungal oligosaccharides) can induce many of the same physiological responses induced by Nod factor (Downie and Walker 2000; Kikuyama et al. 1997; Kuchitsu et al. 1995, 1997; Lamb and Dixon 1997), including membrane depolarization, transient extracellular alkalization, ion fluxes, and the induction of host response genes. The present data extend this parallel and suggest an additional common element, namely the induction of ROS production in response to specific Nod factor signals.

An important goal for future research will be to determine if the similarities between the proposed events of legume Nod factor signal transduction and plant responses to pathogen elicitors share common genetic elements or if separate but related components are operative in the two cases. Activation of early nodulin gene enod 40 by chitin pentamer is suggestive of cross talk between these two phenotypically distinct pathways (Minami et al. 1996). Conversely, nonlegume species can respond to Nod factors by induction of plant gene expression (Reddy et al. 1998; Staehelin et al. 1994). Whether $\mathrm{H}_{2} \mathrm{O}_{2}$ might also be sufficient for induction of other early nodulin genes, such as enod12 and enod40, has not yet been tested, although the nodulation mutant $d m i 1-1$ failed to increase the corresponding transcripts in response to Nod factor or S. meliloti treatments. An intriguing possibility is that the response of legumes to Nod factor may be derived from an ancient conserved pathway for plant responses to certain classes of pathogen elicitors. It will be important to examine ROS and related phenotypes in other nodulation mutants and, ultimately, the cloning of plant genes operative in the symbiotic signaling pathway, such as $d m i 1$, will be crucial to resolving these issues.

\section{MATERIALS AND METHOD}

Plant material, bacterial strains, and growth conditions.

M. truncatula ecotype A17 and its near-isogenic, nonnodulating mutant $d m i$ 1-1 were grown aeroponically and inoculated

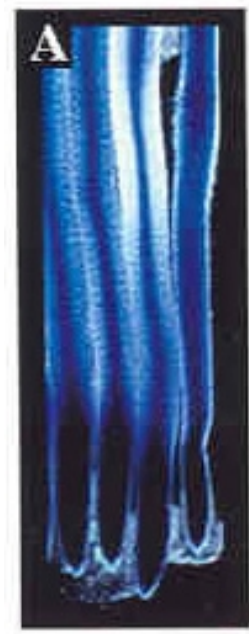

WT

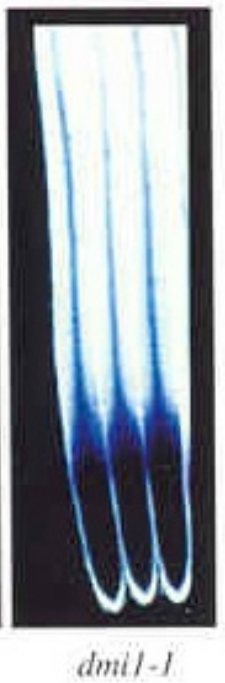

B

(hr post-inoculation) 네뉴:

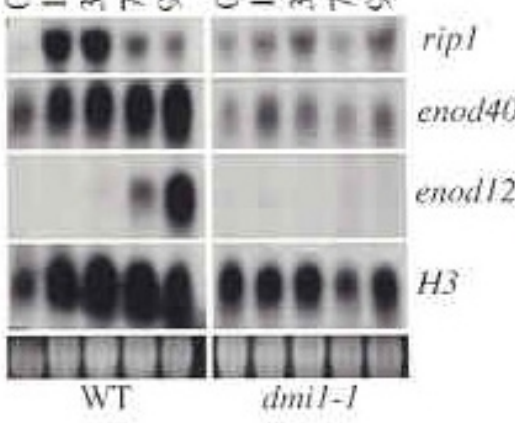

C

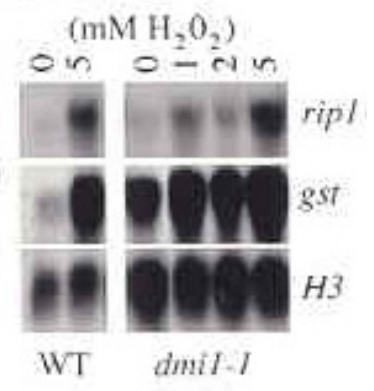

Fig. 6. Analysis of a nonnodulating plant mutant, dmi1-1, for elicitation of reactive oxygen species and early nodulin gene expression. A, Nitroblue tetrazolium (NBT) staining in the wild-type parent A17 (WT) and its nonnodulating mutant dmil-1. Roots were stained with NBT 12 h after inoculation with Sinorhizobium meliloti 2011. B, Northern blot containing total RNA isolated from roots of the wild-type parent A17 (WT) and its nonnodulating mutant dmi1-1 after inoculation with $S$. meliloti 2011. WT and dmi1-1 RNAs were analyzed on the same membrane and represent identical exposure times. The same blot was successively probed with ${ }^{32} \mathrm{P}$-labeled rip1, ENOD12, ENOD40, and histone H3. The time course is reported in hours postinoculation. Note: The increase in histone $\mathrm{H} 3$ transcript observed in response to inoculation of wild-type plants with $S$. meliloti is a nodulation-related response that has been documented in other studies (R. V. Penmetsa and D. Cook, unpublished data). C, Northern blot analysis of dmil-1 plants treated with $\mathrm{H}_{2} \mathrm{O}_{2}$ or mocktreated with nutrient medium. The same blot was successively probed with ${ }^{32} \mathrm{P}$ labeled rip1, gst, and histone H3. 
with S. meliloti as previously described (Cook et al. 1995). Bacterial inoculations were performed using S. meliloti wildtype strains ABS7, 1021, 2011, or strains mutated for nodDIABC (SL44, a gift from S. Long) or nodH (Debelle et al. 1986). For Nod factor treatment, purified Nod factor (a gift from J. Dénarié, CNRS-France) was dissolved in 50\% ethanol and added directly to 101 of inorganic nutrient media (Lullien et al. 1987) in an aeroponic chamber to a final concentration of $5 \times 10^{-9} \mathrm{M}$. Plant material for all experiments was grown in a growth room with a $12 \mathrm{~h}$ photoperiod $\left(18^{\circ} \mathrm{C}\right.$ night and $22^{\circ} \mathrm{C}$ day) and a light intensity of $300 \mu \mathrm{M} \mathrm{m}^{-2} \mathrm{~s}^{-2}$.

\section{Assay for rip1 induction by exogenous $\mathrm{H}_{2} \mathrm{O}_{2}$.}

For studies involving hydrogen peroxide, 5-day-old uninoculated plants were removed from the aeroponic chamber and the roots were immersed in $50 \mathrm{ml}$ inorganic nutrient media (Lullien et al. 1987) containing specified concentrations of $\mathrm{H}_{2} \mathrm{O}_{2}$ (Chen et al. 1996). After $1 \mathrm{~h}$ of incubation, the roots were harvested for Northern blot analysis.

\section{Nucleic acid methods.}

RNA isolation, Northern blot analysis, and in situ hybridization experiments were conducted as previously described (Cook et al. 1995). For analysis of ripl induction by Sinorhizobium strains, shown in Figure 5B, the terminal approximately 3 $\mathrm{mM}$ of the root was removed prior to RNA extraction; this manipulation served to reduce background levels of ripl transcript that were associated with the extreme root tip. Hybridization probes used were ripl (Cook et al. 1995), enod12 (Pichon et al. 1992), enod40 (Crespi et al. 1994), actin, gst, and histone H3. The actin, gst, and histone H3 probes were generated by degenerate polymerase chain reaction (PCR) amplification of DNA from $M$. truncatula ecotype A17 followed by cloning of individual PCR products into pBlueScript vector (Stratagene, La Jolla, CA, U.S.A.). The identity of individual clones was determined by DNA sequence analysis.

In situ hybridizations were performed essentially as described by Cook and associates (Peng et al. 1996). Briefly, root tissue was embedded in paraffin following fixation in $2 \%$ formaldehyde and $0.5 \%$ glutaraldehyde. Sections (8 to $10 \mu \mathrm{m}$ thick) were placed on poly-L-lysine-coated slides for hybridization experiments. Single-stranded rioboprobes were prepared by incorporation of $\mathrm{S}^{35}$-UTP using either T3 or T7 polymerase according to manufacturer's instructions (Stratagene). Antisense probes were used to detect ripl transcript, as shown in Figure 4. Controls consisted of nonhybridized tissue sections and of tissue sections hybridized with sense strand probes of ripl (data not shown). Hybridized transcript was detected with Kodak NBT-2 emulsion, and specimens were observed by bright field optics using a Zeiss (Batavia, IV) Axioskop light microscope.

\section{Superoxide detection by nitroblue tetrazolium.}

For in situ localization of $\mathrm{O}_{2}^{-}, 5$-day-old plants were inoculated with different Sinorhizobium strains or purified Nod factor in an aeroponic chamber. At $12 \mathrm{~h}$ postinoculation, the plants were removed from the aeroponic chamber, and the roots were excised. For NBT staining, the excised roots were incubated for $1 \mathrm{~h}$ at $37^{\circ} \mathrm{C}$ in $10 \mathrm{ml}$ of $10 \mathrm{mM}$ sodium phosphate buffer (pH 7.8) containing $10 \mathrm{mM} \mathrm{NaN}_{3}$ and $0.1 \%$ NBT (Jabs et al. 1997). The stained roots were then cleared in two changes of lactophenol at $65^{\circ} \mathrm{C}$ (Dietrich et al. 1994) and examined with an Olympus SZH10 stereo microscope using dark field optics. For localization of $\mathrm{O}_{2}^{-}$in nodule primordia, whole roots were harvested $60 \mathrm{~h}$ after inoculation with $S$. meliloti. Nodulated roots were first vacuum infiltrated with $10 \mathrm{mM}$ phosphate buffer ( $\mathrm{pH} \mathrm{7.8)}$ and then incubated for $1 \mathrm{~h}$ at $37^{\circ} \mathrm{C}$ in phosphate buffer containing $0.1 \%$ NBT (Jabs et al. 1997). The stained roots were subsequently cleared and analyzed as described above. In treatments involving SOD, the roots were preincubated in $10 \mathrm{ml}$ phosphate buffer containing SOD (2000 U/ml) for $2 \mathrm{~h}$ at $37^{\circ} \mathrm{C}$. After $2 \mathrm{~h}$ of preincubation, $0.1 \% \mathrm{NBT}$ was added to the phosphate buffer and SOD solution and incubated again at $37^{\circ} \mathrm{C}$ for $1 \mathrm{~h}$. Plants preincubated for $2 \mathrm{~h}$ in phosphate buffer without SOD were used as controls in experiments involving SOD. Sectioning of plant material was performed after staining the roots with NBT. Root segments (terminal $2 \mathrm{~cm}$ ) or nodule primordia were embedded in agarose (3\% in water) and sliced into 50 to $70 \mu \mathrm{m}$ width with a DSK microslicer DTK 100 (Ted Pella Inc., Redding, CA, U.S.A.). The sections were subsequently examined with a Zeiss Axioplan-2 compound microscope using bright-field or dark-field optics.

\section{ACKNOWLEDGMENTS}

This research was funded by grants to D. R. C. from the United States Department of Agriculture Nitrogen Fixation and Metabolism Panel (grant no. 9704014) and by the Human Frontier Science Program Organization (grant no. RG0327-1998M). The authors wish to thank D. Kim, N. Krishnamurthy, and D. Dreyer for technical assistance and J. Dénarié and S. Long for providing purified Nod factors and bacterial strains.

\section{LITERATURE CITED}

Bouchez, D., Tokuhisa, J. G., Llewellyn, D. J., Dennis, E. S., and Ellis, J. G. 1989. The ocs-element is a component of the promoters of several T-DNA and plant viral genes. EMBO (Eur. Mol. Biol. Organ.) J 8:4197-4204

Bradley, D. J., Kjellbom, P., and Lamb, C. J. 1992. Elicitor- and woundinduced oxidative cross-linking of proline-rich plant cell wall protein: A novel rapid defense response. Cell 70:21-30.

Catoira, R., Timmers, A. C., Maillet, F., Galera, C., Penmetsa, R. V., Cook, D., Denarie, J., Gough, C. 2001. The HCL gene of Medicago truncatula controls Rhizobium-induced root hair curling. Development 128:1507-1518.

Catoira, R., Galera C., de Billy F., Journet, E. P., Maillet F., Penmetsa, V., Rosenberg C., Gough, C., Cook D., and Denarie J. 2000. Identification of four genes of Medicago truncatula controlling steps in Nod factor transduction. Plant Cell 12:1647-1665.

Chen, W., Chao, G., and Singh, K. B. 1996. The promoter of a $\mathrm{H}_{2} \mathrm{O}_{2}$-inducible, Arabidopsis glutathione S-transferase gene contains closely linked OBF-and OBP1-binding sites. Plant J. 10:955-966.

Cook, D., Dreyer, D. A., Bonnet, D., Howell, M., Nony, E., and VandenBosch, K. 1995. Transient induction of a peroxidase gene in Medicago truncatula precedes infection by Rhizobium meliloti. Plant Cell 7:43-55.

Cook, D. R. 1999. Medicago truncatula - A model in the making! Curr. Opin. Plant Biol. 2:301-304.

Crespi, M. D., Jurkevitch, E., Poiret, M., d'Aubenton-Carafa, Y., Petrovics, G., Kondorosi, E., and Kondorosi, A. 1994. enod40, A gene expressed during nodule organogenesis, codes for a nontranslatable RNA involved in plant growth. EMBO (Eur. Mol. Biol. Organ.) J 13:5099-5112.

Daniel, V. 1993. Glutathione S-transferases: Gene structure and regulation of expression. Crit. Rev. Biochem. Mol. Bio.28:173-207.

Debelle, R., Rosenberg, C., Vasse, J., Maillet, F., Martinez, E., Denarie, J., and Truchet, G. 1986. Assignment of symbiotic developmental phenotypes to common and specific nodulation (nod) genetic loci of Rhizobium meliloti. J. Bacteriol 168:1075-1086.

Dénarié, J., Debellé, F., and Promé, J.-C. 1996. Rhizobium lipo-chitooligosaccharide nodulation factors: Signaling molecules mediating recognition and morphogenesis. Annu. Rev. Biochem 65:503-535.

Dietrich, R. A., Delaney, T. P., Uknes, S. J., Ward, E. R., Ryals, J. A., and Dangl, J. L. 1994. Arabidopsis mutants simulating disease resistance response. Cell 77:565-577.

Doke, N. 1983. Involvement of superoxide anion generation in hypersensitive response of potato tuber tissues to infection with an incompatible race of Phytophthora infestans. Physiol Plant Pathol 23:345347.

Downie, J. A., and Walker, S. A. 1999. Plant responses to nodulation factors. Curr. Opin. Plant Biol. 2:483-489.

Erhardt, D. W., Atkinson, E. M., and Long, S. R. 1992. Depolarization of alfalfa root hair membrane potential by Rhizobium meliloti Nod fac- 
tors. Science 256:998-1000.

Erhardt, D. W., Wais, R., and Long, S. R. 1996. Calcium spiking in plant root hairs responding to Rhizobium nodulation signals. Cell 85:673681

Felle, H. H., Kondorosi, E., Kondorosi, A., and Schultze, M. 1996. Rapid alkalinization in alfalfa root hairs in response to Rhizobial lipochitooligosaccharide signals. Plant J 10:295-301.

Gamaley, I. A., and Klyubin, I. 1999. Roles of reactive oxygen species: Signaling and regulation of cellular functions. Int. Rev. Cytol 188:203255.

Handberg, K., and Stougaard, J. 1992. Lotus japonicus, an autogamous, diploid legume species for classical and molecular genetics. Plant J. 2:487-496.

Jabs, T., Tschope, M., Colling, C., Hahlbrock, K., and Scheel, D. 1997. Elicitor-stimulated ion fluxes and $\mathrm{O}_{2}^{-}$from the oxidative burst are essential components in triggering defense gene activation and phytoalexin synthesis in parsley. Proc. Natl. Acad. Sci. U.S.A. 94:48004805 .

Journet, E.-P., Pichon, M., Dedieu, A., de Billy, F., Truchet, G., Barker, D. G. 1994. Rhizobium meliloti Nod factors elicit cell-specific transcription of the ENOD12 gene in transgenic alfalfa. Plant J. 6:241-249.

Journet, E. P., El-Gachtouli, N., Vernoud, V., de Billy, F., Pichon, M. Dedieu, A., Arnould, C., Morandi, D., Barker, D. G., GianinazziPearson, V. 2001. Medicago truncatula ENOD11: A novel RPRP-encoding early nodulin gene expressed during mycorrhization in arbuscule-containing cells. Mol. Plant Microbe Interact. 14:737-748.

Kikuyama, M., Kuchitsu, K., and Shibuya, N. 1997. Membrane depolarization induced by $\mathrm{N}$-acetylchitooligosaccharide elicitor in suspensioncultured rice cells. Plant Cell Physiol. 38:902-909.

Kieliszewski, M. J., and Lamport, D. T. 1994. Extensin: Repetitive motifs, functional sites, posttranslational codes, and phylogeny. Plant J. 5:157-172.

Kuchitsu, K. Kosaka, H., Shiga, T., and Shibuya, N. 1995. EPR evidence for generation of hydroxyl radical triggered by $\mathrm{N}$-acetylchito-oligosaccharide elicitor and a protein phosphatase inhibitor in suspension-cultured rice cells. Protoplasma 188:138-142.

Kuchitsu, K., Yazaki, Y., Sakano, K., and Shibura, N. 1997. Transient cytoplasmic $\mathrm{pH}$ change and ion fluxes through the plasma membrane in suspension-cultured rice cells triggered by $\mathrm{N}$-acetylchitooligosaccharide elicitor. Plant Cell Physiol. 38:1012-1018.

Lamb, C., and Dixon, R. A. 1997. The oxidative burst in plant disease resistance. Ann. Rev. Plant Physiol. Plant Mol. Biol. 48:251-275.

Levine, A., Tenhaken, R., Dixon, R., and Lamb, C. 1994. $\mathrm{H}_{2} \mathrm{O}_{2}$ from the oxidative burst orchestrates the plant hypersensitive disease resistance response. Cell 79:583-593.

Lobler, M., and Hirsch, A. M. 1993. A gene that encodes a proline-rich nodulin with limited homology to PsENOD12 is expressed in the invasion zone of Rhizobium meliloti-induced alfalfa root nodules. Plant Physiol. 103:21-30.

Long, S. R. 1996. Rhizobium symbiosis: Nod factors in perspective. Plant Cell 8:1885-1898.

Lullien, V., Barker, D. G., de Lajudie, P., and Huguet, T. 1987. Plant gene expression in effective and ineffective root nodules of alfalfa (Medicago sativa). Plant Mol. Biol. 9:469-478.

McKhann, H. I., and Hirsch, A. M. 1994. Does Rhizobium avoid the host response? Curr. Top. Microbiol. Immunol. 192:139-162.

Minami, E., Kouchi, H., Cohn, J. R., Ogawa, T., and Stacey, G. 1996. Ex- pression of the early nodulin, END40, in soybean roots in response to various lipo-chitin signal molecules. Plant J. 10:23-32.

Mylona, P., Pawlowski, K., and Bisseling, T. 1995. Symbiotic nitrogen fixation. Plant Cell 7:869-885.

Oke, V., and Long, S. R. 1999. Bacterial genes induced within the nodule during the Rhizobium-legume symbiosis. Mol. Microbiol. 32:837-849.

Peng, H.-M., Dreyer, D. A., VandenBosch, K. A., and Cook, D. 1996. Gene structure and differential regulation of the Rhizobium-induced peroxidase gene rip1. Plant Physiol. 112:1437-1446.

Penmetsa, R. V., and Cook, D. 1997. A legume ethylene-insensitive mutant hyperinfected by its rhizobial symbiont. Science 275:527-530.

Pichon, M., Journet, E. P., Dedieu, A., de Billy, F., Truchet, G., and Barker, D. G. 1992. Rhizobium meliloti elicits transient expression of the early nodulin gene ENOD12 in the differentiating root epidermis of transgenic alfalfa. Plant Cell 4:1199-1211.

Pingret, J. L., Journet, E. P., and Barker, D. G. 1998. Rhizobium Nod factor signaling: Evidence for a $\mathrm{G}$ protein-mediated transduction mechanism. Plant Cell 10:659-671.

Reddy, P. M., Ladha, J. K., Ramos, M. C., Maillet, F., Hernandez, R. J., Torrizo, L. B., Oliva, N. P., Datta, S. K., and Datta, K. 1998. Rhizobial lipochitooligosaccharide nodulation factors activate expression of the legume early nodulin gene ENOD12 in rice. Plant J. 14:693-702.

Roche, P., Debellé, F., Maillet, F., Lerouge, P., Faucher, C., Truchet, G., Dénarié, J., and Promé, J.-C. 1991. Molecular basis of symbiotic host specificity in Rhizobium meliloti: nodH and nodPQ genes encode the sulfation of lipo-oligosaccharide signals. Cell 67:1131-1143.

Salzwedel, J. L., and Dazzo, F. B. 1993. pSym nod gene influence on elicitation of peroxidase activity from white clover and pea roots by rhizobia and their cell-free supernatants. Mol. Plant-Microbe Interact. 6:127-134

Santos, R., Herouart, D., Puppo, A., Touati, D. 2000. Critical protective role of bacterial superoxide dismutase in Rhizobium-legume symbiosis. Mol. Microbiol. 38:750-759.

Santos, R., Hérouart, D., Sigaud, S., Touati, D., and Puppo, A. 2001. Oxidative burst in alfalfa-Sinorhizobium meliloti symbiotic interaction Mol. Plant Microbe Interact. 14:86-89.

Scheres, B., van de Weil, C., Zalensky, A., Horvath, B., Spaink, H., van Eck, H., Zwartrkruis, F., Wolters, A., Gloudemans, T., van Kammen, A., and Bisseling, T. 1990. The ENOD12 gene product is involved in the infection process during the pea- Rhizobium interaction. Cell 60:1-294.

Staehelin, C., Grado, J., Muller, J., Wiemken, A., Mellor, R. B., Felix, G., Regenass, M., Broughton, W. J., and Boller, T. 1994. Perception of Rhizobium nodulation factors by tomato cells and inactivation by root chitinases. Proc. Natl. Acad. Sci. U.S.A. 91:2196-2200.

Vance, R. P. 1983. Rhizobium infection and nodulation: A beneficial plant disease? Annu. Rev. Microbiol. 37:399-424.

Wais, R. J., Galera, C., Catoira' R., Penmetsa' R. V., Cook, D., Gough, C., Dénarié, J., and Long, S. R. 2000. Early symbiosis mutants of Medicago truncatula show a block in $\mathrm{Ca}++$ spiking. Proc. Natl. Acad. Sci. U.S.A. 97:13407-13412.

Wilson, R. C., Long, F., Maruoka, E. M., and Cooper, J. B. 1994. A new proline-rich early nodulin from Medicago truncatula is highly expressed in nodule meristematic cells. Plant Cell 6:1265-1275.

Zhang, B., Chen, W., Foley, R. C., Buttner, M., and Singh, K. B. 1995. Interactions between distinct types of DNA binding proteins enhance binding to ocs element promoter sequences. Plant Cell 7:2241-2252. 